\title{
Bird nests occupied by Sphecidae wasps in Brazil
}

\author{
Yoshika Oniki (")
}

\begin{abstract}
The present paper reports on additional instances of nest cells of a wasp (Pison sp., Sphecidae) in nests of a hummingbird (Phaethornis ruber, Trochilidae) and a new instance in the nest of a flycatcher (Tolmomyas flaviventris, Tyrannidae).
\end{abstract}

\section{INTRODUCTION}

Wasps of the genus Pison are known to nest in bamboo tubes in Europe (Grandi, 1961). Yoshimoto (1965) reporte on Pison argentatum nesting in holes in lava walls of buildings. Also, Yoshimoto reports that in Thailand $P$. argentatum nests on walls while $P$. punctiforms, $P$. suspiciosum and $P$. strandi use beetle burrows or bamboo tubes to build partitionedcelled nests. In Belém. Pará, Brazil, I reported (Oniki, 1970a, 1970b) the occurrence of nest cells of Pison sp. in ocupied nests of Reddish Hermit, (Phaethornis ruber, Trochilidae). Here I report on nest cells of the same wasp species in oher nests of the same hummingbird, and also from the nest of a Yellow-breasted Flycatcher (Tolmomyias flaviventris, Tyrannidae).

\section{MATERIAL AND METHODS}

In the course of detailed studies of nesting seasons of birds, I returned to the Área de Pesquisas Ecológicas do Guamá of the Instituto de Pesquisas Agropecuárias no Norte (IPEAN) at Belém, from April 1972 to May 1973. In studies of nests of many species of birds, I watched for further occurrences of wasp cells. In some cases, wasps were observed entering a bird's nest while it contained eggs or young. However, bird nests were only collected after the young bird left the nest or the eggs or young were destroyed. Then wasp cells were courted, and placed in jars in the laboratory so that adult wasps could emerge.

\section{RESULTS}

In 1972-1973, I encountered wasp cells in 2 out of 5 nests of Reddish Hermits, Phaethornis ruber, and in one nest of a Yellow. breasted Flycatcher, Tolmomyias flaviventris.

Table I indicates that wasp cells were in nests of 0.6 to $2.7 \mathrm{~m}$ in height. Wasp cells were found in nests during May, June and July. Earlier I (1970b) found wasp cells in June, July, August and October. The number of wasp cells was 7 and 3 in $P$. ruber nests and about 20 in the $T$. flaviventris nest.

The Reddish Hermit nest found on 28 June 1972 , had 2 tiny young. Both young developed in the nest but on 16 July only one young was left. On 17 July the nest was empty. This nest was collected on 31 July 1972, when it had several half-built wasp cells; I put it in a glass jar to obtain emerging wasps.

The other Reddish Hermit nest, found 4 July 1972, had 2 eggs. Two tiny young were in the nest on 16 July. The young were developing in the nest but this was found empty on 27 July. The nest was collected on 1 August. It had 3 wasp cells and they were placed in a jar. Two adult wasps were found dead on 17 September 1972.

The Yellow-breasted Flycatcher nest (Fig. 1) found on 9 May 1972 had 2 eggs. A wasp was first noticed carrying mud and entering the side of the nest on June 6. One or two wasps came 2 times in 2 seconds and cleaned the antenna before leaving the bird nest. On 7 June the wasp was not present but the previous day's cell was closed and another cell was half built. On 8 June the wasp was not present but the second cell was three-fourths completed. On 9 June the wasp was not present but the cells were almost closed. (The two young birds flew out of the nest on 10 June

(") - UNICAMP, Instituto de Biologia, Departamento de Zoologia 
as the nest was touched). On 13 June the wasp was in and repairing the last cell, which was a little damaged by the previous night's rain. On 15 June, the bird nest and an adult wasp were collected soon after it entered the nest with mud. About twenty cells were then separated from the inside of the bird nest and placed in a jar. Dates when emerged adults were found in the jar are as follows:

$$
\begin{array}{rllllll}
2 & \text { July } & \ldots & \ldots & \ldots & 2 \text { Pison, } 2 \text { Trichrysis } \\
5 & \text { July } & \ldots & \ldots & \ldots & 1 & \text { Pison at } 15: 00 \\
9 & \text { July } & \ldots & \ldots & \ldots & 1 & \text { Pison at } 09: 48 \\
9 & \text { July } & \ldots & \ldots & \ldots & 2 & \text { Pison at } 10: 26 \\
12 & \text { July } & \ldots & \ldots & 2 & \text { Pison at } 14: 20 \\
14 & \text { July } & \ldots & \ldots & \ldots & 2 & \text { Pison at } 07: 30 \\
17 & \text { July } & \ldots & \ldots & \ldots & 1 & \text { Pison at } 01: 20 \\
19 & \text { July } & \ldots & \ldots & \ldots & 2 & \text { Pison } \\
21 & \text { July } & \ldots & \ldots & \ldots & 1 & \text { Pison } \\
23 & \text { July } & \ldots & \ldots & & & \\
\end{array}
$$

between 2 and 23 July. 4 Pison

From the Yellow-breasted Flycatcher nest. 18 wasps that emerged were males and 2 were females. The wasp opens one "lid" of its barrel-shaped cell in emerging. Average dimensions of 8 such cells were: $1.3 \mathrm{~cm}$ long and $0.6 \mathrm{~cm}$ wide.

\section{CONCLUSIONS}

According to Table 1, the wasp breeding October. The size of the bird nest seems to season is now known to extend from May to limit the number of wasp cells, because the hummingbird nests had 7 and 3 cells but the larg flycatcher nest had about 20 cells and ohers were still heing built.

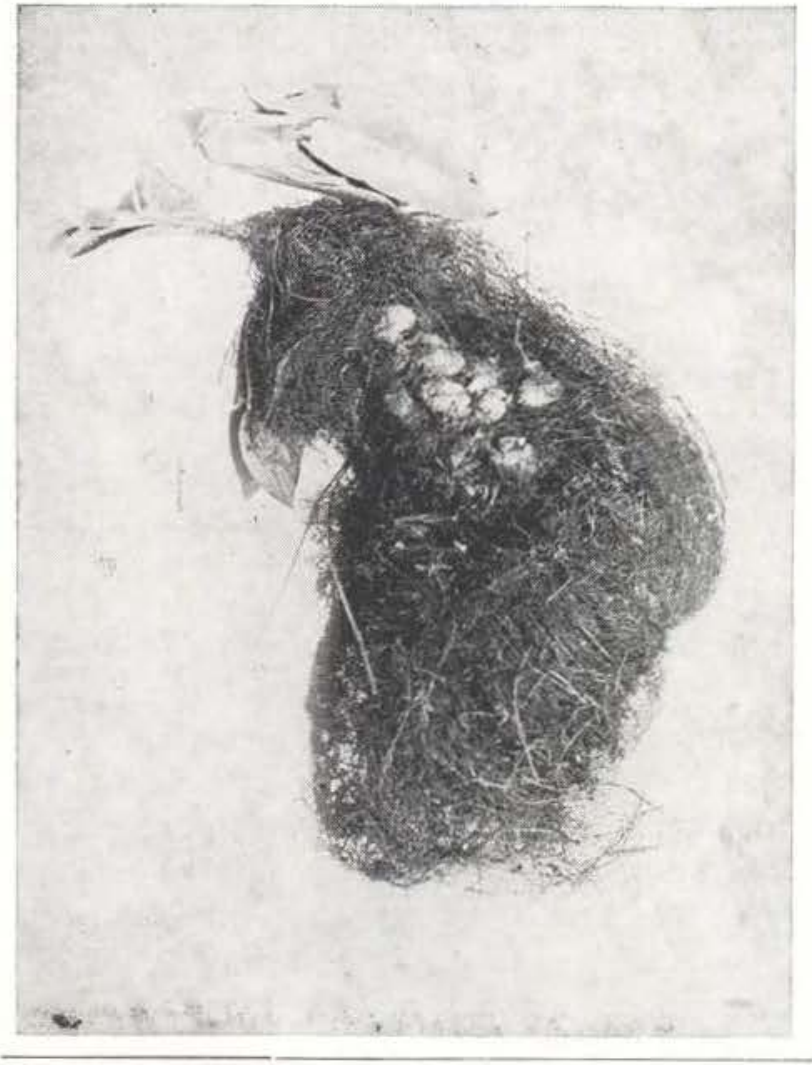

Figure 1. Yellow-breasted Flycatcher nest with Pison sp. cells exposed.

Oniki (1970b) reported on a Brachymeria sp. (Chalcididae) probably a parasite of Pison $\mathrm{sp}$. From the flycatcher nest, besides the Pison specimens, I obtained 2 green wasps, Trichrysis sp., Chrysididae, probably parasites of the Pison sp. Thus two parasitic wasps are now known from the Pison sp. cells. Yoshimoto (1965) found 3 of 7 nests of $P$. argentatum parasitized by an eulophid wasp, Melittobia hawaiiensis and found dermestid exuviae (Trogoderma anthrenoides) in one.

TABLE 1

Nests of $\mathbf{P}$. ruber and $\mathbf{T}$. flaviventris studied in Belém

Species

Phaethornis ruber Phaethornis ruber Phaethornis ruber Phaethornis ruber Phaethornis ruber T. flaviventris
Date found

Contents

30 May 1972

31 May 1972

28 June 1972

4 July 1972

4 October 1972

9 May 1972

empty (building)
empty (building)
2 young
2 eggs
2 young
2 eggs

Kind of tree
murumuru palm
murumuru palm
mumbaca palm
mumbaca palm
palm
Myrcia fallax

$\begin{array}{ccc}\begin{array}{c}\text { Height } \\ \text { of nest }\end{array} & \begin{array}{c}\text { Wosp cell } \\ \text { present }\end{array} & \begin{array}{c}\text { Number of } \\ \text { cells }\end{array} \\ 2,7 \mathrm{~m} & \text { No } & - \\ 0,7 \mathrm{~m} & \text { No } & - \\ 1,5 \mathrm{~m} & \text { Yes } & 7 \\ 0,6 \mathrm{~m} & \text { Yes } & 3 \\ 1,2 \mathrm{~m} & \text { No } & - \\ 1,4 \mathrm{~m} & \text { Yes } & \pm 20\end{array}$


The young wasps emerge well after the young has left the nest. In the case of the flycatcher nest, the wasp was still building new cells at the time the young bird left the nest.

The hummingbird and the flycatcher nests were found in second growth in the middle of old rubber plantations, in rather open areas.

\section{ACKNOWI EDGEMENTS}

This study was supported by the National Science Foundation, Grant $n^{\circ}$ GB-32921, and Conselho Nacional de Pesquisas, TC n 6998-71. Drs. A.S. Menke, and R. M. Bohart identified the wasps. E. O. Willis helped me with the field work and with comments on the manuscript. K. Brown, Jr., helped with the manuscript.

\section{SUMÁRIO}

O presente trabalho relata a re-ocorrência da vespa Pison sp., da familia Sphecidae em ninhos de beija-flor, Phaethornis ruber. Também é relatado uma ocorrência nova da mesma espécie de vespa em ninho de um bem-te-vi, Tolmomyas flaviventris.
Deste ninho, entre os Pison sp. obtidos apareceram duas outras vespas verdes, identificadas como Trichrysis sp., da família Chrysididae, e provável parasita de Pison sp. O número de células de ves. pas encontradas nos ninhos de aves deve ser limitado, pelo tamanho do ninho da ave. As vespas adultas eclodiram sempre algum tempo depois que as aves jovens deixaram o ninho.

\section{LITERATURE CITED}

GRANDI, H.

1961 - Studi di un Entomologo sugli Imenotteri Superiori. Boll. Inst. Entomol. Univ. Bologna, 25.645 p.

IMMS, A. D.

1957 - A General Textbook of Entomology. 9 th. ed. New York, E. P. Dutton. $886 \mathrm{p}$.

ONIKI, Y,

1970a - Nesting behavior of Reddish Hermits (Phaethornis ruber) and occurrence of wasp cells in nests. Auk, 87(4):720-728.

$1970 \mathrm{~b}-$ Brazilian Sphecid wasps in occupied Hummingbird nests. Jour. of the Kansas Entomological Society, 43(4):354-356.

Yosнimoto, C. M.

1965 - Nesting activity of the mud-daubing wasp, Pison argentatum Schuckard, in Hawaii. Pac. Insects, 7:291-294 